Journal Universitas Muhammadiyah Gresik Engineering, Social Science, and Health International Conference (UMGESHIC)

UMGCINMATIC : $1^{\text {st }}$ Rethinking Education during Covid-19 Era: Challange and Innovation

\title{
THE EFFECT OF TAXPAYER AWARENESS ON TAXPAYER COMPLIANCE: THE MODERATING ROLE OF TAXPAYER SANCTIONS
}

\author{
Author \\ Faridatul Khasanah ${ }^{1}$, Suwandi ${ }^{2}$ \\ Universitas Muhammadiyah Gresik ${ }^{1,2}$ \\ faridatulkhsnh@gmail.com ${ }^{1}$, suwandi@umg.ac.id ${ }^{2}$
}

\begin{abstract}
This study aims to test the influence of Tax Awareness on Taxpayer Compliance with tax sanctions as a moderation variable. The population used is private taxpayers who are affected in KPP Pratama Gresik. The sample in this study amounted to 95 selected using purposive sampling technique. This study uses quantitative method with primary data source in the form of the questionnaire. The results of this study show that taxpayer awareness has an effect on taxpayer compliance. Meanwhile, variable moderation of tax sanctions does not moderate or weaken the relationship of taxpayer awareness with taxpayer compliance.
\end{abstract}

Keywords: Taxpayer Awareness, Taxpayer Compliance, Tax Sanction.

\section{INTRODUCTION}

Taxes have a very important role in sustaining the economy in the country, because taxes are used to finance the state aimed at the welfare of the community. According to Law no. 28 of 2007, taxes are mandatory donations to the state owed by individuals or entities that are coercive under the law, without getting direct reciprocity and are used for the benefit of the state for the greatest prosperity of Indonesian citizens.

The state requires large funds to finance all needs in the implementation of development and government spending. And to finance all of these needs, one of the things that is needed and most importantly is the active role of the community in contributing to the state in the form of taxes so that all development needs can be financed. Because basically the community will also receive benefits from the money that has been paid for taxes. Public facilities that can be used today such as roads, toll roads, bridges, and so on are examples of benefits that can be felt by the community. However, there are still quite a lot of taxpayers who do not fulfill their obligations in paying taxes. People feel dissatisfied because they feel they have not yet felt the benefits of the facilities obtained from paying the tax. Such as the uneven development of infrastructure and the many cases of corruption in development projects make people think that funds from taxes are only used by a few people. This then encourages the emergence of non-compliance by taxpayers in fulfilling their obligations. The following is the ratio of 
taxpayer compliance in submitting the annual SPT 2016-2018:

\begin{tabular}{|l|l|l|l|}
\hline Description & 2016 & 2017 & 2018 \\
\hline $\begin{array}{l}\text { Compliance Ratio } \\
-\end{array}$ & $61 \%$ & $73 \%$ & $75 \%$ \\
\hline
\end{tabular}

Table 1.1 Compliance Ratio for SPT WP 2016-2018

Source: www.pajak.co.id

From the table above, it can be seen that the SPT submission compliance ratio increases every year. However, from this increase, the achievement of taxpayer compliance is still low to comply with all tax obligations.

\section{METHODS}

a. Research Sample

According to Sugiyono (2016:149) the sample is part of the number and characteristics possessed by the population. The sample that will be used in this research is 100 individual taxpayers registered at KPP Pratama Gresik, by calculating using the Slovin formula as below:

$$
\begin{aligned}
& \mathrm{n}=\frac{N}{1+N(e)^{2}} \\
& \mathrm{n}=\frac{85.719}{1+85.719(0,1)^{2}} \\
& \mathrm{n}=99.88 \text { (rounded up to } 100)
\end{aligned}
$$

Description:

$\mathrm{n}=$ Number of respondents

$\mathrm{N}=$ Total population

$\mathrm{e}=$ Allowance for tolerance of sampling error accuracy

Sample that will be used in this research is 100 individual taxpayers registered at KPP Pratama Gresik. The sampling technique in this study was carried out using the purposive sampling with certain criteria.

b. Operational and Measurement Definition Variable

1) Dependent Variable

a) Taxpayer Compliance

Taxpayer compliance is a condition when the taxpayer fulfills all tax obligations and fulfill their tax rights. Based on this information, it can be explained that taxpayer compliance is: the attitude of the taxpayer to exercise 
his taxation rights and fulfill his tax obligations.

2) Independent Variable

a) Taxpayer Awareness

Awareness is a condition where we are aware if we know, understand, are aware of, and believe in certain conditions, especially aware of their rights and obligations to pay taxes as good citizens.

3) Moderating Variables

a) Tax Sanctions

Tax sanctions according to (Mardiasmo, 2016:62) are tax sanctions as a guarantee that the provisions of tax laws (tax norms) will be complied with.

In other words Tax sanctions are a preventive tool so that taxpayers do not violate tax norms.

c. Data Analysis Techniques

1) Descriptive Statistics

Descriptive statistical method is used to provide an overview or description of a data which is seen from the minimum, maximum, mean, and standard deviation.

d. Instrument Testing Method

1) Validity Test

Test the validity of the data using the content (face) validity approach. The value of data validity is sought by using the product moment correlation formula. This calculation using the computer-assisted SPSS program. The calculation is carried out using Scale-reliability analysis on the item total statistics table with the corrected item total correlation (Sugiyono \& Susanto, 2015: 388).

2) Reliability Test

The data reliability test uses an internal consistency reliability approach. To measure internal consistency, the researcher used one of the statistical techniques, namely Cronbach's alpha. According to (Ghozali, 2018:52) a variable is said to be valid if the Cronbach alpha value > 0.60 .

e. Classical Assumption Test

1) Normality Test

Normality test is used to test whether in the regression model, the confounding or residual variables have a normal distribution (Ghozali, 2018:111). A good regression model if it has a normal data distribution or not, it can be done graphical analysis or by looking at the normal probability plot that compares the cumulative distribution and the normal distribution. To detect the normality of the data can also be done with the One Sample Kolmogorov-Smirnov test.

2) Multicollinearity Test

The multicollinearity test is used to determine whether the proposed regression model pattern has found a correlation between independent variables (Ghozali, $2018: 105)$ ). The presence or absence of multicollinearity can be seen in the VIF and Tolerance values. If the VIF value is $<10$, and the tolerance value is If the 
value is $>10 \%$, then the conclusion is that there is no multicollinearity disorder in the linear regression equation, on the other hand, if the VIF value is $>10$ and the tolerance is $<10 \%$, then the conclusion is that there is a multicollinearity disorder in the linear regression equation.

3) Heteroscedasticity Test

This test aims to determine whether in the regression model there is an inequality of variance from the residuals of one observation to another observation. A good regression model is the one with homoscedasticity. To detect the presence or absence of heteroscedasticity in this study, a scatterplot was used. Testing for heteroscedasticity if Sig is above 5\%, it is concluded the regression model does not contain heteroscedasticity (Jotopurnomo \& Mangoting, 2013).

f. Data Processing and Analysis Techniques

1) Simple Linear Regression Analysis

The simple linear regression equation is an equation model that describes the relationship between one dependent variable and the independent variable.

$$
Y=a+\beta_{1} X_{1}+e
$$

Description:

$\mathrm{Y} \quad=$ Mandatory compliance tax

$\mathrm{a}=$ Constant

$\beta 1 \mathrm{X} 1=$ Taxpayer awareness

$\mathrm{E} \quad=$ Error

2) Multiple Linear Regression Analysis

Multiple linear regression analysis is an analytical tool related to the study of the dependence of the dependent variable on the independent variable.

$$
\mathrm{Y}=\mathrm{a}+\beta_{1} \mathrm{X}_{1}+\beta_{2} \mathrm{Z}+\mathrm{e}
$$

Description:

$\mathrm{Y}=$ Mandatory compliance tax

$\mathrm{a} \quad=$ Constant

$\beta 1 \mathrm{X} 1=$ Taxpayer awareness

$\beta 2 \mathrm{Z}=$ Sanctions taxation

$\mathrm{E} \quad=$ Error

3) Moderation Regression Analysis

This data analysis technique was chosen to be used because to examine the effect of the independent variable on the dependent variable by using the moderating variable, which is the moderating variable to determine whether the moderating

$$
\mathrm{Y}=\mathrm{a}+\beta_{1} \mathrm{X}_{1}+\beta_{2} \mathrm{Z}+\beta_{3} \mathrm{X}_{1} * \mathrm{Z}+\mathrm{e}
$$


variable can strengthen or weaken the dependent and independent variables. The following form of the regression equation for the moderating variable is as follows:

Description:

$$
\begin{array}{ll}
\mathrm{Y} & =\text { Mandatory compliance tax } \\
\mathrm{a} & =\text { Constant } \\
\beta 1 \mathrm{X} 1 & =\text { Taxpayer awareness } \\
\beta 2 \mathrm{Z} & =\text { Sanction taxation } \\
\beta 3 \mathrm{X} 1 * \mathrm{Z} & =\text { Interaction between taxpayer awareness and sanctions taxation } \\
\mathrm{E} & =\text { Error }
\end{array}
$$

According to Solimun in (Suwandi, 2021) moderating variables are classified into 4 types, namely: Pure Moderation Variables ( pure moderation ), Pseudo Moderation Variables (quasi moderation), Potential Moderating Variables (moderation homologiser), Moderating Predictor Variables (moderation predictor ).

g. Hypothesis Testing

1) Partial Test (Test t)

The t-test is used to test the effect of each independent variable used in this study on the dependent variable partially (Ghozali, 2018 :152)

2) Simultaneous test (F test)

Simultaneous effect test is used to determine whether the independent variables simultaneously or simultaneously affect the dependent variable.

3) Determinant Coefficient Test (R2)

The coefficient of determination is defined as how much influence the independent variable has on changes in the dependent variable. From this it is known how much the dependent variable can be explained by the independent variable, while the rest is explained by other causes outside the model.

\section{RESULT AND DISCUSSION}

a. Descriptive Analysis

\begin{tabular}{|l|r|r|r|r|r|}
\hline & N & Minimum & Maximum & mean & Std. Deviation \\
\hline Taxpayer Compliance & 95 & 23 & 40 & 32.63 & 4.718 \\
Taxpayer Awareness & 95 & 16 & 35 & 27.16 & 3.985 \\
Tax Sanctions & 95 & 10 & 30 & 23.19 & 3.737 \\
Valid N (listwise) & 95 & & & & \\
\hline
\end{tabular}

Table 4. 1 Descriptive Analysis of Research Variables

Source: SPSS Output Results, 2021 
Based on the table above, it can be seen that the number of samples in this study there were 95 respondents. The taxpayer compliance variable has a value of minimum of 23 and a maximum value of 40 , with an average value of 32.63 . Then the taxpayer awareness variable has a minimum value of 16 and a maximum value of 35 , with an average value of 27.16. And the tax sanctions variable has a minimum value of 10 and a maximum value of 30 , by getting an average value of 23.19 .

b. Instrument Test

1) Validity Test

a) Taxpayer Compliance

\begin{tabular}{|l|l|l|l|l|}
\hline Items & R Count & R Table & Significant & Description \\
\hline Y.1 & 0.711 & 0.201 & 0.05 & Valid \\
\hline Y.2 & 0.749 & 0.201 & 0.05 & Valid \\
\hline Y.3 & 0.739 & 0.201 & 0.05 & Valid \\
\hline Y.4 & 0.767 & 0.201 & 0.05 & Valid \\
\hline Y.5 & 0.717 & 0.201 & 0.05 & Valid \\
\hline Y.6 & 0.729 & 0.201 & 0.05 & Valid \\
\hline Y.7 & 0.756 & 0.201 & 0.05 & Valid \\
\hline Y.8 & 0.832 & 0.201 & 0.05 & Valid \\
\hline
\end{tabular}

Table 4. 2 Taxpayer Compliance

Source: SPSS Output Results, 2021

b) Mandatory Awareness Tax

\begin{tabular}{|l|l|l|l|l|}
\hline Items & R Count & R Table & Significant & Description \\
\hline X.1 & 0.674 & 0.201 & 0.05 & Valid \\
\hline X.2 & 0.690 & 0.201 & 0.05 & Valid \\
\hline X.3 & 0.759 & 0.201 & 0.05 & Valid \\
\hline X.4 & 0.660 & 0.201 & 0.05 & Valid \\
\hline X.5 & 0.727 & 0.201 & 0.05 & Valid \\
\hline X.6 & 0.569 & 0.201 & 0.05 & Valid \\
\hline X.7 & 0.588 & 0.201 & 0.05 & Valid \\
\hline
\end{tabular}

Table 4. 3 Taxpayer Awareness

Source: SPSS Output Results, 2021

Based on the table above, it can be seen that the question that has the highest $\mathrm{r}$ count is X.3 of 0.759 while the lowest is X.6 of 0.569 . Questions in the questionnaire on the question of taxpayer awareness can be said to be valid because the value of $r$ count $>r$ table, namely 0.201 .

c) Penalty Taxation

\begin{tabular}{|l|l|l|l|l|}
\hline Items & R Count & R Table & Significant & Description \\
\hline Z.1 & 0.797 & 0.201 & 0.05 & Valid \\
\hline
\end{tabular}


UMGCINMATIC : $\mathbf{1}^{\text {st }}$ Rethinking Education during Covid-19 Era: Challange and Innovation Volume 1 No 2

\begin{tabular}{|l|l|l|l|l|}
\hline Z.2 & 0.713 & 0.201 & 0.05 & Valid \\
\hline Z.3 & 0.754 & 0.201 & 0.05 & Valid \\
\hline Z.4 & 0.620 & 0.201 & 0.05 & Valid \\
\hline Z.5 & 0.789 & 0.201 & 0.05 & Valid \\
\hline Z.6 & 0.699 & 0.201 & 0.05 & Valid \\
\hline
\end{tabular}

Table 4. 4 Tax Sanctions

Source: SPSS Output Results, 2021

Based on the table above, it can be seen that the question that has the highest $\mathrm{r}$ count is Z.1 of 0.797 while the lowest is Z.4 of 0.620 . The questions in the questionnaire on the question of tax sanctions can be said to be valid because the value of $r$ count $>r$ table, namely 0.201 .

c. Assumption Test Classic

1) Test Normality

\begin{tabular}{|c|c|c|}
\hline \multicolumn{3}{|c|}{ One-Sample Kolmogorov-Smirnov Test } \\
\hline & & $\begin{array}{c}\text { Unstandardized } \\
\text { Residual }\end{array}$ \\
\hline $\mathrm{N}$ & & 95 \\
\hline \multirow[t]{2}{*}{ Normal Parameters a,b } & mean & .0000000 \\
\hline & Std. Deviation & 3.29456045 \\
\hline \multirow[t]{3}{*}{ Most Extreme Differences } & Absolute & .076 \\
\hline & Positive & .076 \\
\hline & negative & -.055 \\
\hline Test Statistics & & .076 \\
\hline asymp. Sig. (2-tailed) & & $200 \mathrm{c,d}$ \\
\hline
\end{tabular}

a. Test distribution is Normal.

b. Calculated from data.

c. Lilliefors Significance Correction.

d. This is a lower bound of the true significance.

Table 4. 6 Normality Test

Source: SPSS Output Results, 2021

Based on the table above, using the Kolmogorov-Smirnov One Sample for the normality test above, it can be seen that the Kolmogrov-Smirnov $\mathrm{Z}$ or Test Statistics has a value of 0.076 with a significance value of 0.200 . Indicates that the significance value is greater than $0.05(0.200>0.05)$. So it can be concluded that the normality test of the data from this study is normally distributed or the assumption of normality of the data has been met. 
2) Test Multicollinearity

The following are the results of the multicollinearity test which are presented in the table below:

\section{Coefficients a}

\begin{tabular}{|c|c|c|c|c|c|c|c|c|}
\hline \multirow{2}{*}{\multicolumn{2}{|c|}{ Model }} & \multicolumn{2}{|c|}{$\begin{array}{c}\text { Unstandardized } \\
\text { Coefficients }\end{array}$} & \multirow{2}{*}{$\begin{array}{c}\begin{array}{c}\text { Standardized } \\
\text { Coefficients }\end{array} \\
\text { Beta }\end{array}$} & \multirow[b]{2}{*}{$\mathrm{t}$} & \multirow[b]{2}{*}{ Sig. } & \multicolumn{2}{|c|}{$\begin{array}{c}\text { Collinearity } \\
\text { Statistics }\end{array}$} \\
\hline & & B & Std. Error & & & & Tolerance & VIF \\
\hline 1 & (Constant) & 9,286 & 2.496 & & 3,721 & .000 & & \\
\hline & Taxpayer Awareness & .813 & .114 & .687 & 7.138 & .000 & .573 & 1,747 \\
\hline & Tax Sanctions & .054 & -121 & .043 & .448 & .655 & .573 & 1,747 \\
\hline
\end{tabular}

a. Dependent Variable: Taxpayer Compliance

Table 4. 7 Multicollinearity Test Results

Source: SPSS Output Results, 2021

Based on the results of the multicollinearity test in the table above, it shows that the tolerance value of each independent variable is 0.573 . The tolerance value has a value greater than 0.10 . And the VIF value of all independent variables is 1.747 . The researcher concludes that the above test can be said that there is no multicollinearity between independent variables in the regression model because the VIF value of each variable $<10$.

\section{3) Test Heteroscedasticity}

The results of the heteroscedasticity test in this study can be seen in the following figure:

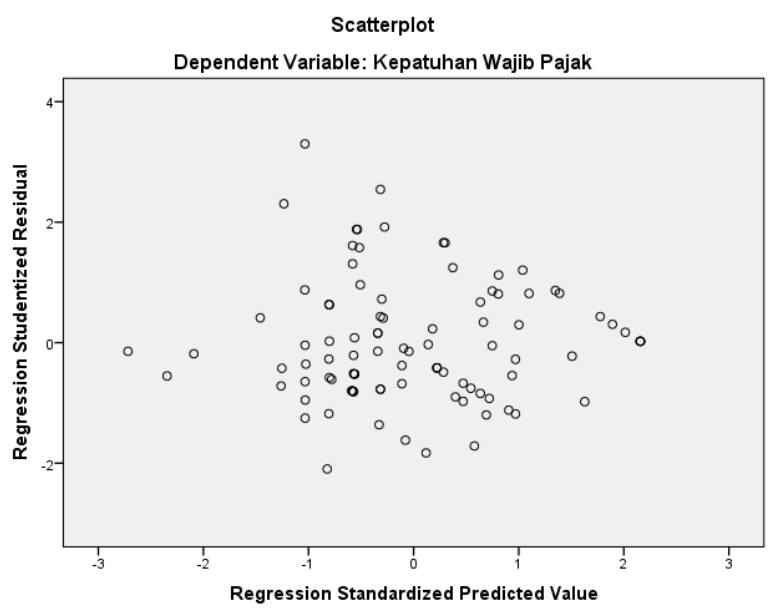

Figure 4. 1 Results of Heteroscedasticity Test

Source: SPSS Output Results, 2021 
Based on the scatterplot graph above, the dots spread randomly and do not form a pattern. The points are spread above and below the number 0 on the $\mathrm{Y}$ axis, so it can be concluded that there is no heteroscedasticity problem in the regression model.

d. Hypothesis Test

The following are the results of the t-statistical test, as shown in the table below this:

Table 4. 11 T-Test Results of Regression Model III

Coefficients ${ }^{\text {a }}$

\begin{tabular}{|c|c|c|c|c|c|c|c|c|}
\hline \multirow{2}{*}{\multicolumn{2}{|c|}{ Model }} & \multicolumn{2}{|c|}{$\begin{array}{c}\text { Unstandardized } \\
\text { Coefficients }\end{array}$} & \multirow{2}{*}{$\begin{array}{c}\text { Standardized } \\
\text { Coefficients } \\
\text { Beta }\end{array}$} & \multirow[b]{2}{*}{$\mathrm{t}$} & \multirow[b]{2}{*}{ Sig. } & \multicolumn{2}{|c|}{$\begin{array}{c}\text { Collinearity } \\
\text { Statistics }\end{array}$} \\
\hline & & B & Std. Error & & & & Tolerance & VIF \\
\hline \multirow[t]{4}{*}{1} & (Constant) & 17,448 & 12.856 & & 1.357 & .178 & & \\
\hline & Taxpayer Awareness & .504 & .491 & .426 & 1.027 & .307 & .031 & 32.224 \\
\hline & Tax Sanctions & -.295 & .554 & -.234 & -.533 & .595 & .028 & 36,100 \\
\hline & $\begin{array}{l}\text { WP Awareness*Tax } \\
\text { sanctions }\end{array}$ & .013 & .020 & 492 & .647 & .519 & .009 & 108.142 \\
\hline
\end{tabular}

a. Dependent Variable: Taxpayer Compliance

Source: SPSS Output Results, 2021

Based on the table above, the significance value for taxpayer awareness and tax sanctions is $0.519>0.05$. From these results, the value of $t$ count is $0.647<\mathrm{t}$ table 1.661404 . So it can be concluded that the awareness of taxpayers with tax sanctions has no significant effect on taxpayer compliance or $\mathrm{H} 2$ is rejected.

\subsubsection{Simultaneous Test (F Test)}

Table 4. 12 F-Test Results of Regression Model III

ANOVA ${ }^{a}$

\begin{tabular}{|ll|r|r|r|r|r|}
\hline \multicolumn{1}{|l|}{ Model } & Sum of Squares & df & Mean Square & F & \multicolumn{1}{c|}{ Sig. } \\
\hline 1 & Regression & 1076,493 & 3 & 358,831 & 32,152 & $.000 \mathrm{~b}$ \\
& Residual & 1015,612 & 91 & 11.161 & & \\
& Total & 2092.105 & 94 & & & \\
\hline
\end{tabular}

a. Dependent Variable: Taxpayer Compliance

b. Predictors: (Constant), WP Awareness ${ }^{\star}$ Tax sanctions, Taxpayer Awareness, Tax Sanctions

Source: SPSS Output Results, 2021

Based on the table above, the calculated $F$ value is 32.152 with a significant $F$ of 0.000 . In this study df1 has a value of 3 and df 2 has a value of 91 . so that the F table obtained is 2.71 . So it can be concluded that the variables of taxpayer awareness, tax sanctions and taxpayer awareness moderated by tax sanctions affect taxpayer compliance, because the calculated $\mathrm{F}$ value is $32.152>2.71$ with a significance level of $0.000<0.05$. 


\subsubsection{Coefficient of Determination (Adjust R squares)}

The following is the result of the coefficient of determination, as shown in the table below this :

Table 4. 13 Coefficient of Determination of Model I

\begin{tabular}{|l|c|r|r|c|}
\hline \multicolumn{7}{|c|}{ Model Summary } \\
Model & $\mathrm{R}$ & $\mathrm{R}$ Square & $\begin{array}{c}\text { Adjusted R } \\
\text { Square }\end{array}$ & $\begin{array}{c}\text { Std. Error of the } \\
\text { Estimate }\end{array}$ \\
\hline 1 & $.715^{\mathrm{a}}$ & .511 & .506 & 3.316 \\
\hline
\end{tabular}

a. Predictors: (Constant), Total_X

Source: SPSS Output Results, 2021

Based on the table above, the adjusted $R$ square value is 0.506 , which means that taxpayer compliance is influenced by taxpayer awareness of 0.506 or $50.6 \%$ and the rest is explained by other factors.

Table 4. 14 Coefficient of Determination Model II

\begin{tabular}{|l|r|r|r|r|r|}
\hline \multicolumn{7}{|c|}{ Model Summary } \\
\hline Model & $\mathrm{R}$ & R Square & $\begin{array}{c}\text { Adjusted R } \\
\text { Square }\end{array}$ & $\begin{array}{c}\text { Std. Error of the } \\
\text { Estimate }\end{array}$ & Durbin-Watson \\
\hline 1 & .716 a & .512 & .502 & 3.330 & 1.451 \\
\hline
\end{tabular}

a. Predictors: (Constant), Tax Sanctions, Taxpayer Awareness

b. Dependent Variable: Taxpayer Compliance

Source: SPSS Output Results, 2021

Based on the table above, the adjusted $R$ square value is 0.502 , which means that taxpayer compliance is influenced by taxpayer awareness and tax sanctions of 0.502 or $50.2 \%$ and the rest is explained by other factors.

Table 4. 15 Coefficient of Determination Model III

\begin{tabular}{|l|c|r|r|r|r|}
\hline \multicolumn{1}{|c|}{ Model Summary b } \\
\hline Model & $\mathrm{R}$ & R Square & $\begin{array}{c}\text { Adjusted R } \\
\text { Square }\end{array}$ & $\begin{array}{c}\text { Std. Error of the } \\
\text { Estimate }\end{array}$ & Durbin-Watson \\
\hline 1 & .717 a & .515 & .499 & 3.341 & 1.509 \\
\hline
\end{tabular}

a. Predictors: (Constant), WP Awareness ${ }^{\star}$ Tax sanctions, Taxpayer Awareness, Tax

Sanctions

b. Dependent Variable: Taxpayer Compliance

Source: SPSS Output Results, 2021

Based on the table above, the adjusted $R$ square value is 0.499 or $49.9 \%$. It can be concluded that from the regression model I to the regression model II and III the adjusted $R$ square value decreased by 0.s 7\%, which means that taxpayer compliance is not influenced by taxpayer awareness with tax sanctions as a moderating variable. 


\subsection{Interpretation of Results}

\subsubsection{Influence of Taxpayer Awareness on Taxpayer Compliance}

Based on the results of the hypothesis test conducted, it shows that the taxpayer awareness variable has a significant and significant effect on the taxpayer compliance variable. It can be concluded that taxpayers who are aware of their tax obligations will increase the level of taxpayer compliance. Taxpayers who know the existence of the tax law and know the function of taxes, will calculate, pay, and report their taxes voluntarily. This is because the taxpayer knows that the tax paid by the taxpayer will be used for the development of infrastructure and facilities for the benefit of the community.

The results of this study are in accordance with research conducted by (Budhiartama \& Jati, 2016) that when consciousness the higher the taxpayer, the compliance taxpayers in pay more taxes high . (Siat \& Toly, 2013) also states that taxpayer awareness increases taxpayer compliance.

\subsubsection{The effect of tax awareness on taxpayer compliance with tax sanctions as follows: moderator}

Based on the results of hypothesis testing using tax sanctions as a moderating variable, it shows that the tax sanctions variable has no effect or weakens the taxpayer awareness variable on taxpayer compliance. Tax sanctions have been regulated in such a way in the tax law, but the applicable sanctions are still considered to be less firm against taxpayer violators in creating taxpayer awareness in paying taxes so that taxpayer compliance does not increase.

The tax sanctions given do not strengthen in a direction that is not in the same direction (negative) and is not significant with taxpayer awareness of taxpayer compliance because tax sanctions are still considered less firm to violators so that the tax sanctions are underestimated by violators. Research result

This is in accordance with research conducted by (Yanti et al., 2021) that the tax sanctions variable is not able to moderate the effect of taxpayer awareness on taxpayer compliance.

In addition, researchers want to see with the derivative equation of the interaction of taxpayer compliance variables with taxpayer awareness as proxies for tax sanctions, obtained the equation $\frac{y}{x 1}+0,504+0,013$ and to determine the point of intersection with the $\mathrm{X}$ axis then $\frac{y}{x 1}=0$ so that it becomes a tax sanction $=0,504: 0,013$; the point of intersection of the $\mathrm{X}$ axis ( $38,769: 0$ ). To determine the point of intersection of the $\mathrm{Y}$ axis then $\mathrm{X}=0 ;=0,504$; Yintercept $(0,504: 0)$. So that the image of the moderating variable can be determined as follows:

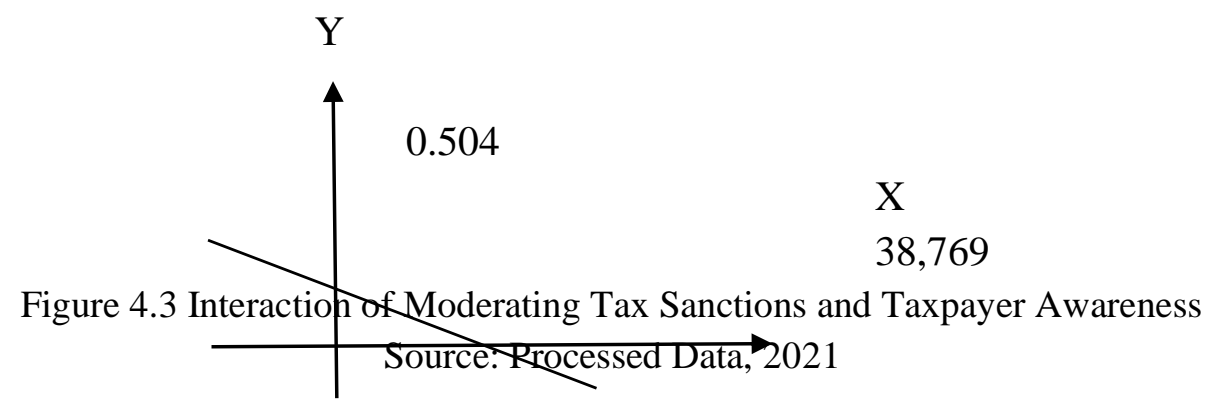

Based on Figure 4.3 shows that tax sanctions weaken the relationship between taxpayer awareness and taxpayer compliance, then the relationship between tax sanctions with taxpayer awareness and taxpayer compliance remains unaffected. In addition, based on the results of the regression test, it shows that if 2 is not significant and 3 is not significant, then the tax sanctions 
variable is included in the category of potential moderating variable (moderation homologiser), namely the moderating variable that has the potential to be a moderating variable.

\section{CONCLUSIONS AND SUGGESTIONS}

a. Conclusions

Based on the results of research that has been carried out by researchers, the conclusions from the previous discussion are as follows. Return on Assets has a significant effect on firm value.

1) Taxpayer awareness has a significant effect on taxpayer compliance

2) Tax sanctions do not moderate the relationship between taxpayer awareness and taxpayer compliance. The moderating variable in this study is classified as a moderating homologist because the moderating variable does not have a significant relationship with the dependent variable.

b. Suggestions

Based on the conclusions from the results carried out by researchers, suggestions that can be given for improvement in further research are as follows.

1) In future research, it is hoped that other independent variables can be added as factors that can have a strong influence on mandatory compliance taxes such as tax socialization, understanding of taxpayers, tax costs.

2) In future research, it is expected to be able to replace other moderating variables, or by replacing other types of variables such as the variable control.

\section{REFERENCES}

Budhiartama, IGP, \& Jati, IK (2016). The Effect of Attitude, Taxpayer Awareness And Tax Knowledge On Compliance Paying Land And Building Tax. E-Journal of Accounting , 15 (2), 1510-1535.

Directorate General of Taxes, Law No. 28 of 2007 concerning General Provisions and Tax Procedures.

Ghozali, I. 2018. Application of Multivariate Analysis SPSS 25 (9th ed.) . Semarang: Diponegoro University.

Ilhamsyah, R., \& et al. (2016). The Effect of Taxpayer's Understanding and Knowledge of Tax Regulations, Taxpayer Awareness, Service Quality, and Tax Sanctions on Motor Vehicle Taxpayer Compliance. Journal of Chemical Information and Modeling , 8, 19.

Jatmiko, AN (2006). The Influence of Service Quality, Tax Sanctions and Compliance Fees on Taxpayer Compliance. E-Journal of Accounting , 86.

Jotopurnomo, C., \& Mangoting, Y. (2013). The influence of taxpayer awareness, quality of service of the tax authorities, tax sanctions, the taxpayer's environment is on the compliance of individual taxpayers in Surabaya. Tax \& Accounting Review , 1 , 51.

Lestari, EMP, H, LB, \& Pranaditya, A. (2018). The Effect of Tax Services and Tax Sanctions on Taxpayer Compliance with Awareness of Paying Taxes as an Intervening Variable 
(Case Study at KPP Pratama Semarang Candisari). Journal Of Accounting , 4 (4), 20. Mardiasmo. 2016. Taxation Latest Edition 2016 . Yogyakarta: CV Andi.

Megawangi, CAM, \& Setiawan, PE (2017). Tax Socialization Moderates the Effect of Taxpayer Awareness and Service Quality on Corporate Taxpayer Compliance. EJournal of Accounting , 19 (3), 2348-2377.

Mutia, SPT (2014). The effect of tax sanctions, tax awareness, tax service services, and level of understanding on individual taxpayer compliance (Empirical Study on Individual Taxpayers registered at KPP Pratama Padang. Scientific Article , 2 (1), 2-29.

Nugroho, A., Andini, R., \& Raharjo, K. (2016). The Effect of Taxpayer Awareness and Taxpayer Knowledge of Taxpayers on Taxpayer Compliance in Paying Income Tax. Journal Of Accounting , 2 (2), 1-13.

Permatasari, A., \& Yaniartha, P. d'ya. (2012). The Influence of Wp Awareness And Tax Sanctions On Wp Compliance In Paying The United Nations. E-Journal of Accounting $, 1(2), 1-15$.

Santika, KA (2015). The Effect of Wp Awareness, Service Quality, and Tax Sanctions on Groundwater Wp Compliance. E-Journal of Accounting , 12 (3), 656-670.

Sapriadi, D. (2013). The effect of tax service quality, tax sanctions and taxpayer awareness on taxpayer compliance in paying PBB (In Selupu Rejang District). Journal of Accounting.

Siahaan, Marihot Pahala. 2013. Revised Edition Regional Taxes and Levies. Jakarta: PT. King of Grafindo

Siat, CC, \& Toly, AA (2013). Factors Affecting Taxpayer Compliance in Fulfilling the Obligation to Pay Taxes in Surabaya. Airlangga Journal of Accounting and Business Research, 1 .

Soemarso. (1998). The Impact of the 1984 Tax Reformation on the Efficiency of the Indonesian Taxation System. Economics and Finance in Indonesia , 46 (i), 333-366.

Sugiyono. 2016. Quantitative, Qualitative and $R \& D$ Research Methods . Bandung: Alphabeta.

Suriambawa, A., \& Setiawan, PE (2018). Tax Socialization Moderates the Effect of Taxpayer Awareness and Tax Sanctions on WPOP Compliance. E-Journal of Accounting , 25, 2185.

Susmita, PR, \& Supadmi, N. luh. (2016). The Influence of Service Quality, Tax Sanctions, Tax Compliance Fees, And The Implementation Of E-Filing On Taxpayer Compliance. E-Journal of Accounting , 14 (2), 1239-1269. Kelvin, S. (2021). Political Connection Strengthening Good Corporate Governance Against Tax Avoidance. Accountability, 14 (1), 101-112.

Utami, A. Wandika Putri. (2019). The Effect of Taxpayer Awareness and Tax Sanctions on Taxpayer Compliance. Scientific Journal , 1 (3), 111-117.

Winerungan, OL (2013). Socialization of Taxation, Fiscus Services and Tax Sanctions Against Wpop Compliance in Kpp Manado and Kpp Bitung. Journal of Economic Research, Management, Business And Accounting , 1 (3), 960-970. 
Yanti, KEM, Yuesti, A., \& Bhegawati, D. Ayu S. (2021). The Influence of Njop, Attitudes, Taxpayer Awareness, Tax Knowledge, and Sppt On Taxpayer Compliance In Paying Land And Building Taxes With Tax Sanctions As Moderating Variables In North Denpasar District. Journal of Chemical Information and Modeling , 3 (1).

Yolina. 2009. Fundamentals of Tax Accounting . Tabora Media. Yogyakarta.

Yuliara, IM (2016). Simple Linear Regression . Simple Linear Regression, 13.

Zain, Mohammad. 2007. Tax Management . Salemba Four. Jakarta 